\title{
Montaigne on His Essays: Toward a Poetics of the Self . Carl H. Klaus
}

How often and perhaps how stupidly have I extended my book to make it speak of itself!

BY THE TIME he made this exclamation - in his final essay, "Of Experience" (818)-Montaigne had good reason to wonder at how often he had indulged in writing about his essays. Had he actually bothered to make a methodical survey of his work, he would have found that it "turns in upon itself" in his prefatory note "To the Reader" and in 27 of his 107 essays. ${ }^{1}$ He would also have found that in most of these 27 essays, such self-regarding comments are not confined to just a sentence or two, but take up several paragraphs, often scattered over two or three pages or more. And he would have found that this preoccupation manifests itself more often and at greater length as he moves from Book I to Book II to Book III of his essays, so that it gradually becomes a leitmotif of the work as a whole. But such findings probably would not have led him to eliminate or reduce such reflexive passages. Indeed, in keeping with his avowedly contrary and unpredictable behavior, Montaigne chose to expand many of these passages in the process of revising his work. In the final version of his essays, for example, he turned the exclamatory statement that opens this piece into a full paragraph by adding two lengthy sentences which end in a justification of writing about his writing, "because my theme turns in upon itself ..." (818).

Having made this excuse for essaying his essays, Montaigne immediately wondered whether his readers would "accept it" and thereby allay his fear of having "stupidly" engaged in the very self-regarding activity he had previously scorned in others. Far from exposing himself to ridicule, he established a very alluring precedent, for essayists to this day have continued to write about their essays, about other essayists, and about the nature of the essay itself. ${ }^{2}$ Montaigne not only set this self-reflexive precedent, but he also defined most of the issues that concern subsequent essayists on the essay. So, Montaigne's self-reflexive comments are significant both as 
an embodiment of his thinking about the essay and as a harbinger of subsequent ideas of the essay.

In the course of reflecting on his essays, Montaigne covers almost the entire spectrum of topics that might be of interest to an essayist or student of the essay-from composing and revising his essays to editing and publishing them, from their purpose and content to their form and style, including matters as varied as the titles, the length, the intelligibility, and the truth of his essays. In commenting on these topics, however, Montaigne rarely stops to reflect at length on any single aspect of his writing. Indeed, "being a sworn enemy of obligation, assiduity, perseverance" (76), he often shifts abruptly from one idea or experience or allusion to another, no matter what topic he happens to be discussing. As he moves from one essay to the next, or one book of essays to the next, or one edition of the essays to the next, he often returns to issues he has discussed before, but sometimes he takes a different slant on the matter, so much so that by his own admission he contradicts himself "now and then" (611).

Though scattered, undeveloped, and sometimes contradictory, Montaigne's reflections on his writing do, I think, center on an interrelated set of issues that can be discerned if one surveys his comments collectively from beginning to end. In particular, they persistently engage issues related to Montaigne's unprecedented self-absorption, his radical subjectivity, and his bold refusal to abide by the canons of scholastic specialization:

I speak my mind freely on all things, even on those which perhaps exceed my capacity and which I by no means hold to be within my jurisdiction. And so the opinion I give of them is to declare the measure of my sight, not the measure of things. (298)

Authors communicate with the people by some special extrinsic mark: I am the first to do so by my entire being, as Michel de Montaigne, not as a grammarian or a poet or a jurist. (611)

Given so keen an awareness that his essays constituted "a new and extraordinary amusement" (273), "the only book in the world of its kind" (278), it is hardly surprising that he might have been moved to celebrate all the distinctive aspects and elements of his globally subjective enterprise. 
Indeed, Montaigne's persistent comments and reflections on his writing punctuate the essays like advertisements or fanfare for his new literary venture-as exuberantly unrestrained as his essays themselves. Collectively, they constitute a dramatic embodiment of Montaigne's anti-scholastic approach, offering not a methodical rhetoric, but a flamboyant antirhetoric, of the essay.

Yet it is also clear that these persistent reflections on his writing were occasioned not just by the impulse to celebrate his subjectivity, but also by a preoccupation with the problematics of making himself "the matter of [his] book." Indeed, in reading through Montaigne's comments on his writing, one cannot help noticing how frequently they turn back upon himself, no matter what particular aspect of his essays he happens to be discussing. In reflecting on his use of other authors, for example, he touches on a number of pertinent issues, such as the value of compendia, the injustice of plagiarism, and the pretentiousness of extensive allusions. But his reflections ultimately bear witness to the struggle he evidently went through in trying to convey his own ideas, to be true to his own train of thought, while also being unavoidably conscious of how deeply influenced he was by his admittedly extensive reading. At one point, for example, he goes out of his way to make clear that he quotes others not as authority, but as a means of self-expression: "I do not speak the minds of others except to speak my own mind better" (108). At another point, he claims that "when I write, I prefer to do without the company and remembrance of books, for fear they may interfere with my style. Also because, in truth, the good authors humble and dishearten me too much" (666). As these comments suggest, Montaigne keenly felt the anxiety of influence, despite the fact that he lived in an era before it became a central preoccupation of literary consciousness. Thus, here as elsewhere, Montaigne's comments on his writing persistently reflect his concern with finding a viable form in which and through which to explore himself, express himself, and write about himself.

The richness and complexity of Montaigne's thoughts on this problem are prefigured in his brief opening note "To the Reader":

This book was written in good faith, reader. It warns you from the outset that in it I have set myself no goal but a domestic and private one. I have had no thought of serving either you 
or my own glory. My powers are inadequate for such a purpose. I have dedicated it to the private convenience of my relatives and friends, so that when they have lost me (as soon they must), they may recover here some features of my habits and temperament, and by this means keep the knowledge they have had of me more complete and alive.

If I had written to seek the world's favor, I should have bedecked myself better, and should present myself in a studied posture. I want to be seen here in my simple, natural, ordinary fashion, without straining or artifice; for it is myself that I portray. My defects will be read to the life, and also my natural form, as far as respect for the public has allowed. Had I been placed among those nations which are said to live still in the sweet freedom of nature's first laws, I assure you I should very gladly have portrayed myself here entire and wholly naked.

Thus, reader, I am myself the matter of my book; you would be unreasonable to spend your leisure on so frivolous and vain a subject. (2)

In this prefatory note, Montaigne clearly identifies himself as the subject of his essays, but his manner is so provocative, so paradoxical, so playful even, as to suggest right off that the note is in part an elaborate literary gesture designed to overcome some of the uneasiness that he must have felt as a result of having made himself "the matter" of his book. Lacking any notable precedents for so solipsistic an enterprise, Montaigne must have wondered how to defend himself against the obvious charge of being arrogantly preoccupied with himself. As if to forestall such a charge, he repeatedly disclaims any interest in his "own glory" or in "the world's favor." Indeed, he carries this self-deprecatory posture so far as to conclude with the declaration that his avowed subject is "frivolous and vain." In a similarly paradoxical vein, he reiteratively disavows any interest in the reader whom he addresses so solicitously. In a variety of ways, then, this prefatory note is so hyperbolically at war with itself as to seem like a rhetorical tour de force, intended to disarm his potential critics by amusing them with its witty contradictions.

In its playful way, however, this brief note also constitutes a pointed manifesto, a literary declaration of independence from the fundamental 
assumptions and practices of classical rhetoric and medieval scholasticism. The revolutionary nature of Montaigne's enterprise comes through most directly, of course, in his bold assertion that "I am myself the matter of my book," an assertion which immediately makes clear that his book is not a conventional treatise in philosophy, theology, or any other field of knowledge. No less revolutionary is his insistent repudiation of interest in his nominal reader, for such disclaimers tacitly challenge the fundamental premises of any rhetorical enterprise. In one sense, of course, Montaigne's dismissal of the reader-his arhetorical posture-constitutes the most powerful way of authenticating his concern with himself. But in another sense, his repeated attentions to the reader suggest a desire on his part not to repudiate the reader altogether so much as to repudiate a conventionalized relationship of writer and reader. This seemingly paradoxical treatment of the reader ultimately speaks for a desire to reconstitute the relationship along new lines, according to which presumably the reader will make none of the usual expectations in reading Montaigne, but will follow him no matter how "frivolous and vain," or wandering and unpredictable, he may seem to be. In this respect, the note seems to be making a claim for something very much like a rhetorical carte blanche.

Montaigne also challenges traditional conventions here by declaring his commitment to a "simple, natural, ordinary fashion." In keeping with this stance, he openly rejects "a studied posture," much as he rejects any kind of "straining or artifice." This rebellious preference for being natural rather than artificial, "naked" rather than "bedecked," is justified by Montaigne on the grounds of its connection to his overriding concern with himself - "it is myself that I portray." Given this intention to present himself as authentically as possible, to "keep the knowledge" that his relatives and friends have had of him "more complete and alive," Montaigne commits himself to a way of writing that he ultimately associates with an Edenic vision of purity and simplicity, reflected in the "sweet freedom of nature's first laws." The essay, in effect, is presented here as being a kind of writing that hearkens back to an unfallen - prerhetorical - world. From the very start, then, Montaigne overtly allies the essay with an antiworldly impulse, and by extension with an anti-conventional style. And as if to confirm the rebelliousness of his essays, he concludes this address to the reader by openly acknowledging the anti-pragmatical nature of their focus upon "so frivolous and vain a subject." 
Though Montaigne dwells in this note on his commitment to a "simple, natural, ordinary fashion," he also reveals here some of the conditions that work against a literal-minded conception and fulfillment of that ideal. In the first two sentences of the second paragraph, for example, though he explicitly distinguishes worldly forms of writing from his own personal style, he implicitly suggests that his commitment to natural form entails a self-consciously public gesture. To say, for example, that "If I had written to seek the world's favor, I should have bedecked myself better" does not deny the act of having bedecked himself even under the present circumstances. Similarly, to assert that "I want to be seen here in my simple, natural, ordinary fashion, without straining or artifice" suggests that he looks upon his writing as a public performance, calculatedly contrived to make a visible impression of naturalness in an apparently effortless way. So, too, his statement that "it is myself that I portray" evokes the image of Montaigne sitting for his own self-portrait. Montaigne's consciousness of being in the public eye becomes most pronounced in the next three sentences, when he openly acknowledges that his "natural form" can only be followed "as far as respect for the public has allowed," and that he feels constrained by the conventions of public discourse, because he does not live in one of those nations that are governed by the "sweet freedom of nature's laws." This passage, then, has the residual effect of depicting Montaigne's essays as an inherently problematic kind of writing, in that they arise out of an impulse to be completely free of rhetorical constraints, yet they presumably take a form that is to some extent influenced by those constraints. ${ }^{3}$

Montaigne's implicit conception of his essays as a problematic mode of self-portraiture is complicated most of all by his idea of the self, which he identifies with his thoughts more than with any other dimension of his being:

What I chiefly portray is my cogitations, a shapeless subject that does not lend itself to expression in actions. It is all I can do to couch my thoughts in this airy medium of words. (274)

As this passage suggests, Montaigne's idea of self-portraiture involves him in the very difficult, if not impossible, task of depicting his "cogitations." The difficulty, as he makes poignantly clear through the metaphor of 
painting, arises out of an attempt to give visible form and shape to something that is essentially invisible and "shapeless," to "portray" something that is essentially intangible, especially given the intangibility, the "airy medium," of language itself.

But Montaigne represents the problem in even more complex terms, for he conceives of the self as being most authentically reflected not just in thoughts per se, but in the flow of thought, in the process of meditation. To portray himself, in other words, requires not an exposition of his thoughts, but a depiction, as it were, of his mind in the process of thinking. For Montaigne, then, the ultimate challenge is to convey the experience of thinking itself:

It is a thorny undertaking, and more so than it seems, to follow a movement so wandering as that of our minds, to penetrate the opaque depths of its innermost folds, to pick out and immobilize the innumerable flutterings that agitate it. (273)

As he defines the problem in this passage, it is caused in part by the very digressive habit of the mind, which he depicts as being so dynamic in its "wandering," so given to "movement," to "innumerable flutterings," that "to follow" it is, indeed, "a thorny undertaking." In fact, as his final metaphor suggests, the thorniness is caused by attempting not only to track the flow of one's thought, but also to record the flow and thus "immobilize" it at the very same time that one is immersed in the process of thinking. Thus the undertaking is, indeed, "more [thorny] than it seems," because it entails a perceptual juggling act that is logically impossible without a radical division of mental consciousness into subject and object, into the observer and the thing observed. Montaigne's ultimate goal, then, is to depict the self as it is known only by the self alone.

Given his commitment to this dizzying mental task, Montaigne evidently went to extraordinary lengths to devise a way of generating his essays that would leave his mind free to follow its own inclinations, as well as enable him to follow and record its wandering movements as closely and as accurately as possible. He describes or reflects on his composing process in numerous passages, and collectively they create the impression that his writing arises out of a process so free of any mental preplanning, outlining, structuring, rearranging, or editing as to be completely uninhibited: 
I let my thoughts run on, weak and lowly as they are, as I have produced them, without plastering and sewing up the flaws ... (107)

I take the first subject that chance offers. They are all equally good to me. And I never plan to develop them completely. (219)

I have no other marshal but fortune to arrange my bits. As my fancies present themselves, I pile them up; now they come pressing in a crowd, now dragging single file. (297)

Here, as elsewhere, Montaigne claims to write "without a plan and without a promise" (219), "without definitions, without divisions, without conclusions" (483), "without any system" (824). His composing process, as he describes it in these and other such passages, is purportedly so spontaneous, so free from any kind of artificial manipulation or intervention on his part, that he appears to be something of a passive agent, whose thoughts take whatever direction they will, and thus whose essays are shaped by "chance" and "fortune" rather than by personal intention or intervention-by "nature" rather than "by art." Indeed, he implicitly depicts himself in these passages not as an author, carefully planning and shaping his material, but as an amanuensis, slavishly recording and piling things up as they come to mind, "without plastering and sewing up the flaws." Montaigne is presumably so eager to let his mind follow its own bent and to include all of its ramblings that he claims to "pile up only the headings of subjects," rather than obliging himself to develop them into "numberless essays" (185). For similar reasons, he refuses to be distracted by the bother of correcting the punctuation or spelling of his essays (666-7, 736-7). In fact, he declares himself at one point to be opposed to correction of any kind, because he does not wish to misrepresent himself by excluding "the imperfections that are ordinary and constant in me." (667). It seems quite fitting, then, that in the last of his comments on writing, he refers to his work as "this fricassee that I am scribbling" (826).

Just as he avows an uninhibited composing process, so Montaigne also proclaims his prose to be free from any mechanical or methodical constraints - "My style and my mind alike go roaming" (761). In keeping 
with this image of a style attuned to the freedom of his mind, Montaigne repeatedly characterizes his prose as being "natural," "simple," "ordinary," "plain," or "free," rather than "artificial," "affected," "pedantic," "studied," or "strained." Montaigne's eagerness to distinguish his writing from traditional forms of composition becomes so intense that in his later essays he tends to use increasingly more extreme adjectives and figures to reinforce the contrast, referring to his own writing, for example, as "crude," "harsh," "disjointed," "imperfect," or "undisciplined" and to traditional types as "even," "orderly," "polished," and "smooth." Much as he disclaims any polish in his style, so he disavows any structure in his essays or in his work as a whole:

I want the matter to make its own divisions. It shows well enough where it changes, where it concludes, where it begins, where it resumes, without my interlacing it with words, with links and seams introduced for the benefit of weak or heedless ears, and without writing glosses on myself. (761)

The scholars distinguish and mark off their ideas more specifically and in detail. I, who cannot see beyond what I have learned from experience, without any system, present my ideas in a general way, and tentatively. As in this: I speak my meaning in disjointed parts, as something that cannot be said all at once and in a lump. Relatedness and conformity are not found in low and common minds such as ours. (824)

In these and numerous other passages, Montaigne clearly and unrelentingly contrasts his work with the methodical discourse of classical rhetoric and medieval scholasticism, and as if to reinforce the contrast he directly expresses his impatience with Cicero's "way of writing, and every other similar way," with "his prefaces, definitions, partitions, etymologies," claiming that "these logical and Aristotelian arrangements are not to the point" (301). Montaigne's objections to such highly formalistic and logical "arrangements" were occasioned obviously by his sense that they were expressive of a mental certitude about the nature of things that he did not possess - "If my mind could gain a firm footing, I would not make essays, I would make decisions; but it is always in apprenticeship and on trial" 
(611). So it is that he self-consciously espoused an unstructured mode of writing attuned to his sense of the mind's wandering movement and thus of his frequently shifting perception of things. By pitting himself so clearly and so persistently against Aristotle, Cicero, and the medieval scholastics, Montaigne established the now conventional posture of the essayist as an independent, often skeptical mind, exploring ideas and experience outside the confines of received or prevailing intellectual structures. In doing so, he established the essay as an open form of writing, at odds with systematized bodies of knowledge and systematized modes of transmitting knowledge: 6

Learning treats of things too subtly, in a mode too artificial and different from the common and natural one. . . If I were of the trade, I would naturalize art as much as they artify nature. (666)

Yet even in the act of staking out so iconoclastic and libertarian a role for himself and for the essay, Montaigne was evidently quite conscious, as implied by his prefatory note and by the numerous comments bearing witness to his elaborately contrived attempts at "free writing," that his own composing process and his own prose were not so free and natural as they might seem. As early as the first edition, for example, in speaking of his "harsh" style (483), he acknowledges that "I am quite conscious that sometimes I let myself go too far, and that in the effort to avoid art and affectation, I fall back into them in another direction" (484). By the second edition, he openly admits that his way of writing is deliberately calculated to create the illusion of being a free and natural activity:

I go out of my way, but rather by license than carelessness. My ideas follow one another, but sometimes it is from a distance, and look at each other, but with a sidelong glance. I have run my eyes over a certain dialogue of Plato, a fantastic motley in two parts, the beginning part about love, all the rest about rhetoric. The ancients do not fear these changes, and with wonderful grace they let themselves thus be tossed in the wind, or seem to. The titles of my chapters do not always embrace their matter; often they only denote it by some sign, like those 
other titles, The Maid of Andros, The Eunuch, or those other names, Sulla, Cicero, Torquatus. I love the poetic gait, by leaps and gambols. It is an art, as Plato says, light, flighty, daemonic. There are works of Plutarch's in which he forgets his theme, in which the treatment of his subject is found only incidentally, quite smothered in foreign matter. See his movements in "The Daemon of Socrates." Lord what beauty there is in these lusty sallies and this variation, and more so the more casual and accidental they seem.

It is the inattentive reader who loses my subject, not I. Some word about it will always be found off in the corner, which will not fail to be sufficient, though it takes little room. I seek out change indiscriminately and tumultuously. My style and my mind alike go roaming. (761)

From the beginning to the end of this passage, Montaigne seeks to dispel any notion that his essays are the product of undisciplined thinking and writing. Indeed, Montaigne is so concerned here to distinguish his intentional digressiveness from authorial carelessness or casualness that he devotes this lengthy passage to defining, illustrating, and explaining a revolutionary concept of textual coherence which accounts for the unity of his work. He defines this concept in the second sentence, by means of an arresting personification which endows his "ideas" with the capacity to "follow one another, but . . . from a distance, and look at each other, but with a sidelong glance." As this personification suggests, Montaigne conceives of his ideas as being so deeply allied to each other and attuned to each other that their inner cohesiveness has the power to overcome the surface digressiveness of his prose. Having defined his special theory of coherence, Montaigne then proceeds to cite the classical precedents for it in Plato's Phaedrus and Plutarch's "The Daemon of Socrates," carefully drawing out the parallels between these works and his own by noting that "the ancients . . . let themselves . . be tossed in the wind, or seem to." This repeated concern with a calculatedly wrought impression of digressiveness reaches its climax at the end of the first paragraph in Montaigne's exclamatory transformation of the concept into an esthetic principle"Lord what beauty there is in these lusty sallies and this variation, and more so the more casual and accidental they seem." In this bold exclama- 
tion, Montaigne openly avows his commitment to a policy not of naturalness, but of studied casualness, or to be more exact, of artful artlessness. Indeed, in the paragraph immediately following this exclamation, he brashly declares that "it is the inattentive reader who loses my subject, not I. Some word about it will always be found off in a corner, which will not fail to be sufficient, though it takes little room" (761). According to this extended set of reflections, Montaigne depicts his essays as the outcome of a complex mental balancing act, in which he lets his thoughts wander freely enough so that they seem to be "casual" and "accidental," yet keeps them sufficiently controlled so that they do "follow one another," no matter how superficially disconnected they may seem to be. ${ }^{7} \mathrm{He}$ conceives of his writing, then, as being at once the embodiment and the enactment of a mind freely following its own changeable directions - a paradoxical conception of essayistic form that is echoed by essayists as varied as Adorno, Gass, Gerould, Hardwick, Hoagland, Kazin, and White.

Given this conception of his essays, Montaigne clearly recognized that they call for a correspondingly radical approach to reading and interpretation, the nature of which he insinuates throughout the previous passage. For example, in discussing both his essays and their classical precedents, he focuses attention on aspects of their form that defy the conventional expectations of readers, such as chapter titles that "do not always embrace their matter," abrupt "changes" in "subject" from one part of a piece to the next or even from one sentence to the next, and statements of "theme" that can be "found only incidentally, quite smothered in foreign matter . . . off in a corner, which will not fail to be sufficient, though it takes little room." Elsewhere, in a similar vein, he acknowledges that his essays are filled with "stories" and "quotations" that "often bear, outside of my subject, the seeds of a richer and bolder material, and sound obliquely a subtler note, both for myself, who do not wish to express anything more, and for those who get my drift" (185). Given such a welter of apparently distracting or misleading elements, Montaigne's essays, as he recognizes, are certain to confound an "inattentive reader," especially one who is accustomed to methodically written texts that contain "links and seams introduced for the benefit of weak and heedless ears" (761). His essays, in other words, cannot be literally interpreted, because they do not assert their meaning in the forthright and systematic ways that characterize rhetorical and scholastic discourse. Indeed, given their allusive, digressive, disjunctive, ellip- 
tical, and suggestive form, his essays require instead a reader especially attuned to following him on all of his mental jaunts, a reader who like him "love[s] the poetic gait, by leaps and gambols." Thus, in this passage as in others, Montaigne emphatically allies his essays with texts that use language imaginatively and thus require literary rather than literal interpretation.

The need for such interpretation is especially compelling in the case of Montaigne's numerous statements about the subjectivity of his work. Most of these widely scattered comments contain echoes of his prefatory assertion that "I am myself the matter of my book," so one can easily be lulled into taking them at face value, as reiterations and reaffirmations of his self-regarding activity. But from one such passage to the next, Montaigne tends to express somewhat different attitudes or ideas about the reflexivity of his work and to invoke correspondingly different metaphors pertaining to its reflexivity, as if he were trying out different ways of conceiving, defining, and expressing the relationship between his essays and himself. Accordingly, it seems appropriate to examine these passages in detail, not only because they bear directly upon the subjective orientation that Montaigne claimed to be the hallmark of his essays, but also because in doing so they tacitly explore an aspect of the essay that has perennially fascinated essayists and students of the essay-namely, the persona of the essayist and its relationship to the essayist's self. ${ }^{8}$

In some passages, Montaigne depicts his essays as being so intimately connected to himself and authentically expressive of himself as to be indistinguishable from himself, indeed, identical with himself:

It is not my deeds that I write down; it is myself, it is my essence. (274)

In other cases, one may commend the work apart from the workman; not so here; he who touches the one touches the other. (611)

Everyone recognizes me in my book and my book in me. (667)

By equating his book and himself in such hyperbolic terms, Montaigne confers upon each the qualities of the other. To read his essays, then, is to 
partake of his essential being - that is to say, his thoughts, not his deeds as surely as if one were literally in his presence, or, for that matter, in the presence of his mind itself; and to be in his presence is presumably to partake of his book as surely as if one were literally reading his essays - "he who touches the one touches the other."

But in other statements, clearly at odds with these striking equations, Montaigne portrays his writing as being in some sense distinctly different from himself. To some extent, the difference results from what appears to be an unavoidable obedience to the rules and etiquette of public discourse:

There is no description equal in difficulty, or certainly in usefulness to the description of oneself. Even so one must spruce up, even so one must present oneself in an orderly arrangement, if one would go out in public. Now, I am constantly adorning myself, for I am constantly describing myself. (273)

Here, as in his prefatory note (2), Montaigne acknowledges the necessity to "spruce up . . . in public," so it might seem at first glance that he is simply referring to the act of censoring or editing his thoughts to fit the rules of public taste. But by this point it should be clear from his preoccupation with the natural flow of his thought that he is ultimately concerned in this passage with the manipulation or distortion of the flow that inevitably arises from the exigency of having to put one's thoughts in a publicly intelligible form - "in an orderly arrangement, if one would go out in public." So, he implies, the movement from inner speech to written text results willy-nilly in the creation of a persona that is in some respects dissimilar from his own sense of himself. Thus in the final sentence of the passage he metaphorically portrays the discrepancy between his writing and his thinking, between his book and himself, as being an inexorable state of affairs - "I am constantly adorning myself, for I am constantly describing myself."

This inexorable difference, as Montaigne makes clear, also arises from the intimate relationship between himself and his work, a relationship that paradoxically divides them even as it ties them to one another, much as a parent and child inescapably grow apart from each other despite their manifold ties to each other: 
To this child, such as it is, what I give I give purely and irrevocably, as one gives to the children of one's body. The little good I have done for it is no longer at my disposal. It may know a good many things that I no longer know and hold from me what I have not retained and what, just like a stranger, I should have to borrow from it, if I came to need it. If I am wiser than it, it is richer than I. (293)

In this haunting passage from early in Book II of his essays, Montaigne conveys the painful sense of distance that has already developed between himself and his work, though the work is still in progress, a distance so great that he looks upon his book as being "like a stranger." That distance, as his metaphor suggests, is the ineluctable consequence of changes that Montaigne himself has undergone. He is, after all, no longer the same person who wrote the essays preceding this passage. His mind is not in possession of, or possessed by, the thoughts that occupy his book. Indeed, he is "wiser" than his work by virtue of being fully open to experience and change as his book can never be, no matter how much he might revise it and expand it, while at the same time his book is "richer" than he by virtue of retaining everything with which Montaigne has endowed it, much of which he himself may have forgotten or forsaken.

Given such a clear and evocative assertion of the difference between his work and himself, it seems inconceivable that Montaigne could elsewhere have laid claim to such a close identity between his work and himself. But as if to defy logic, he maintains these two diametrically opposed positions at one point within a single passage:

In modelling this figure upon myself, I have had to fashion and compose myself so often to bring myself out, that the model itself has to some extent grown firm and taken shape. Painting myself for others, I have painted my inward self with colors clearer than my original ones. I have no more made my book than my book has made me-a book consubstantial with its author, concerned with my own self, an integral part of my life; not concerned with some third-hand, extraneous purpose, like all other books. (504) 
In the first two sentences of this passage, Montaigne depicts himself as having had to compose his thoughts so often in order to make them publicly acceptable and intelligible that he has gradually developed a persona that differs in some respects from his own inner sense of himself. Presumably, he has done nothing more than smooth out the rough and potentially disagreeable edges of his thought, but the process has led him to believe that he has "painted [his] inward self with colors clearer than [his] original ones." So, it would seem from these first two sentences that Montaigne thinks of his work as being somehow different from himself. But in the third sentence, he manages to transform the difference into a source of identity, by means of an arresting turn of thought, in which he conceives of a reciprocal relationship between his essays and himself-"I have no more made my book than my book has made me." By recognizing that the act of writing is doubly formative - that the self is both the shaper and the thing shaped-Montaigne is able not only to resolve the contradiction, but also to make the extraordinary claim that his work is "consubstantial with its author." In this striking conceit, as in no other moment in his essays, Montaigne lays claim to a unique, indeed mystical, identity between his book and himself.

This boldly religious metaphor has understandably attracted considerable scholarly attention, so much so that some commentators have taken it to be a dominant emblem for Montaigne's conception of the relationship between his essays and himself. ${ }^{9}$ But the closest that he ever comes elsewhere in the essays to affirming or reinforcing the consubstantiality of his book and himself is in the three very brief passages that I have already cited $(274,611,667)$. In other cases, by contrast, he refers to the book quite simply as a "history," "memoir," or "record" of his "reveries," "ideas," or "thoughts" $(504,611,721,751,826)$, and in doing so tacitly makes a clear distinction between his essays and himself. In still other cases, he refers to his writing as a "confession," a means of "revealing" himself, or of making himself known $(109,242,273,296,495,751)$ and in doing so tacitly conceives of it neither as a static record, nor as a consubstantial being, but as a devout activity. And in yet another set of passages, more numerous and extensive than the others, he refers to his work as a "painting" or "selfportrait" $(2,242,274,296,496,504,574,610 / 11,667,677,721,749$, 809). This metaphor, as distinguished from the others, implies that his 
work constitutes an artistic likeness, rather than a replication, record, or revelation, of his self.

In trying to construe this mix of metaphors, I have been strongly tempted to focus on the image of the book as self-portrait, to give this metaphor the heaviest interpretative weight, not only because it appears more frequently and pervasively than any of the others, but also because Montaigne's fascination with the art of self-portraiture can be traced back at least to 1559, some twelve years before he began work on the essays, when he "saw King Francis II presented, in remembrance of Rene, King of Sicily, with a portrait that this king had made of himself" (496). The idea of the book as self-portrait is especially appealing, because it invites a richly suggestive line of comparison with the obsessive self-portraits of Dürer, particularly with the epistemological and technical problems of simultaneously observing and portraying oneself that Dürer had already confronted in the visual medium of painting. But Montaigne does not seem to have been aware of Dürer's self-portraits, nor does he ever invoke the metaphor of painting to explore analogous problems between visual and verbal self-portraiture. In fact, as can be seen from the parenthetical page references cited above, the metaphor of self-portraiture often appears side by side with one or more of the others. And over the course of these passages, Montaigne does not give any clear indication as to which metaphor takes precedence. In the passage analyzed above (504), the metaphor of consubstantiation clearly supersedes that of self-portraiture. But in other cases, Montaigne moves so quickly from one metaphor to the other that he seems to be using them almost interchangeably or synonymously:

Others form man; I tell of him, and portray a very particular one, very ill-formed, whom I should make very different from what he is if $I$ had to fashion him over again. But now it is done.

Now the lines of my painting do not go astray, though they change and vary. The world is but a perennial movement. All things in it are in constant motion - the earth, the rocks of the Caucasus, the pyramids of Egypt - both with the common motion and with their own. Stability itself is nothing but a more languid motion.

I cannot keep my subject still. It goes along befuddled and 
staggering, with a natural drunkenness. I take it in this condition, just as it is at the moment I give my attention to it. I do not portray being: I portray passing. Not the passing from one age to another, or, as the people say, from seven years to seven years, but from day to day, from minute to minute. My history needs to be adapted to the moment. I may presently change, not only by chance, but also by intention. This is a record of various and changeable occurrences, and of irresolute and, when it so befalls, contradictory ideas: whether I am different myself, or whether I take hold of my subjects in different circumstances and aspects. So, all in all, I may indeed contradict myself now and then; but truth, as Demades said, I do not contradict. If my mind could gain a firm footing, I would not make essays; I would make decisions; but it is always in apprenticeship and on trial. (611)

In this well known passage from the opening of "Of Repentance," Montaigne seems at first to be especially committed to the metaphor of self-portraiture, for he announces it at the opening of the first paragraph, returns to it again at the opening of the second, and then builds upon it through the first half of the third paragraph. Indeed, the image he develops of trying to paint a subject that is continually in motion seems a consummately effective way of suggesting the ambitiousness - and the hopelessness - of the challenge he has set for himself in trying to convey through language the incessant flow of his thought. But, as if in keeping with the Heraclitean truth of the passage, he suddenly abandons the metaphor of self-portraiture in mid-paragraph and proceeds to define the exceptional nature of his task by depicting himself as a chronicler attempting to record the history of events that are changing from moment to moment a task made all the more difficult because he is himself changing from moment to moment. Montaigne's metaphors thus reinforce one another here, like expressive variations upon a theme, as he spirals towards the climax of these reflections on the inextricable relationship between the motions of his mind and the movement of his prose - "If my mind could gain a firm footing, I would not make essays, I would make decisions."

Given the restless state of mind that Montaigne acknowledges here and elsewhere, it is hardly surprising that he did not ever settle upon a single 
metaphor or single point of view in reflecting on his essays and himself. At some moments, evidently, he regarded his work as being so faithful an expression of his thoughts, of his mind in action, as to be virtually identical, indeed "consubstantial," with himself, or at least to be an authentic revelation of himself. At other times, just as obviously, he regarded his book as being more nearly an artistic representation, or at least a reconstruction, of his thinking and thus referred to it as a portrayal of himself, or as a history or record of himself. So, he often wavered among the different metaphors and their differing implications. Yet on some occasions, he apparently saw so little difference among the metaphors as to use them interchangeably or to resolve their contradictions by a leap of wit or faith. In other words, Montaigne did not maintain a "firm" or stable conception of his work and its relationship to himself, except, of course, for his unremitting desire to bring it "to fidelity" (611). In relentlessly pursuing that goal, and in relentlessly reflecting upon his pursuit of it, Montaigne endowed the essay with an intense consciousness of consciousness that has been, perhaps, its most enduring and definitive quality.

To conclude this piece simply by noting Montaigne's unstable view of the relationship between his work and himself must seem like a small return for so large an investment of time and effort as was involved in tracking down, sorting, and analyzing his numerous and widely scattered comments on his writing. And in a sense, the return is quite small, particularly when measured against the more expansive, definitive, and conclusive view that readers ordinarily crave of any writer who absorbs them so much as I have been by Montaigne. Indeed, my instincts in this respect have led me to make several attempts at pulling together the various strands of his thinking on the various topics he discusses, so as to produce something here at the end like an explicit definition or summation of his poetics. Yet each attempt has led me to experience anew how persistently Montaigne's reflections on his writing resist codification. Oh yes, he does unequivocally locate himself and his work in opposition to the rhetorical and scholastic heritage of classical and medieval discourse, and in doing so he clearly establishes the essay as an antigenre, as a kind of writing whose distinguishing characteristic is its freedom from the strictures of methodical form and thought. But in the process of enunciating and elaborating 
this coherent and overarching position, he repeatedly seems to be poised between two or more assertions or attitudes or stances that cannot be tidily resolved. At some moments he claims to record the natural flow of his thoughts exactly as they come to mind, but at other moments he acknowledges the record of his thinking to be an elaborately contrived performance, though contrived in order to reflect something like his actual thoughts and habits of mind. At some moments he perceives his work to be of a piece with himself, but at other moments he regards it as being more nearly like a revelation or a self-portrayal or merely a chronicle of himself. At some moments he disavows any interest in the reader, at other moments he clearly seeks to realign the reader toward the special mode of reading and interpretation he considers necessary to an understanding of his work. So, any formulation of his poetics would have to reflect his wavering view of virtually everything from the inception to the reception of his essays.

To some extent, of course, these unstable views may be attributed to changes in outlook and practice that took place quite naturally over the twenty years that Montaigne was working on his essays. In his first book of essays, for example, most of which are relatively brief, he espouses a preference for short pieces by claiming that "I cut myself off so often for lack of breath; I have neither composition nor development that is worth anything." Whereas in his third book of essays, most of which are much longer than those in the first two books, he has altered his view of the matter: "Because such frequent breaks into chapters as I used at the beginning seemed to me to disrupt and dissolve attention making it disdain to settle and collect for so little, I have begun making them longer, requiring fixed purpose and assigned leisure."

Such unstable views may also be attributed to the unprecedented nature of Montaigne's literary venture. Lacking any clearcut antecedents or models for the essay, other than such remotely connected works as the Platonic dialogues and the Senecan epistles, he must often have felt uncertain about exactly how to fulfill his professed commitment to a natural way of writing. Indeed, given his decision to be guided by the freedom of nature rather than the rules of art, Montaigne could not avoid a substantial amount of uncertainty both in composing his essays and in reflecting on them. In writing his essays, he was, after all, venturing into terra incognita, 
so it is hardly surprising that his perception of the territory might be somewhat indeterminate and unstable.

In another respect, however, such unstable views are the quintessence of the essay as Montaigne conceived of it:

If my mind could gain a firm footing, I would not make essays;

I would make decisions; but it is always in apprenticeship and on trial. (611)

This conception of the essay as the embodiment and enactment of a writer's mental indeterminacy implicitly calls for a reader who, in turn, is not only willing, but even eager, to "go roaming" in a text that moves "by leaps and gambols" and thus does not ever provide "a firm footing." Indeed, this spacious view of the essay invites one not to "make decisions" or reach conclusions, but to be "always in apprenticeship and on trial," to be as open to exploration as the essayist. So, to conclude simply by noting Montaigne's unstable view of the relationship between his work and himself is, after all, to affirm a way of reading that keeps pace with all the sallies and excursions of his mind.

\section{ACKNOWLEDGMENTS}

This study was completed with the assistance of the Brodbeck Faculty Fellowship in the Humanities (1988), for whjich I am grateful to the University of Iowa. I am also grateful to my colleagues Deborah Laycock and James Marshall for their helpful reactions to manuscript revisions of this piece.

\section{Notes}

1. For specific passages, see Book I, "To the Reader" (2), "Of Idleness" (21), "Of Prompt or Slow Speech" (26, 27), "Ceremony of Interviews Between Kings" (32), "Of the Power of Imagination" (76), "Of Pedantry" (100), "Of the Education of Children" (107, 108, 109, 127), "Of Friendship" (135), “A Consideration upon Cicero" $(184,185)$, "Of Democritus and Heraclitus" (219), "Of Vain Subtleties" (227), "Of Prayers" $(229,234)$; Book II, "Of the Inconsistency of our Actions" 
(242), "A Custom of the Island of Cea" $(251,253)$, "Of Practice" (272, 273, 274), "Of the Affection of Fathers for their Children" (278, 279, 293), "Of Books" (296, 297, 298, 300), "Apology for Raymond Sebond" $(425,426)$, "Of Presumption" (482, 483, 484, 494, 495, 496), "Of Giving the Lie" (503, 504, 505), "Of the Resemblance of Fathers to Children" (574, 595, 596); Book III, "Of the Useful and the Honorable" (599), "Of Repentance" (610, 611, 612), “On Some Verses of Virgil” (642, 644, 666, 667, 668, 677, 678), "Of the Art of Discussion" (703, 705, 718, 720, 721), "Of Vanity" (721, 734, 735, 736, 737, 749, 750, 751, 759, 761, 762), "Of Physiognomy" (808, 809, 811), “Of Experience" (818, 824, $825,826,837,838$ ).

2. For a discussion of the essay as conceived and defined in this body of commentary, see Klaus.

3. For alternative readings of this passage, see O'Neill, 1-10, and Starobinski, 29-31.

4. For specific passages, see 2, 26, 76, 127, 219, 297, 298, 484, 611, 666.

5. For specific passages, see 76, 127, 483, 484, 761, 824, 826.

6. For a discussion of the essay as a genre inherently at odds with systematized and institutionalized modes of gathering and transmitting knowledge, see Anderson, Good, 3-8, Kauffmann, and Klaus.

7. For an alternative reading of this passage and its implications for a conception of the essay, see Bensmaia, 5-8.

8. For example, see Gass, Gerould, Good, Hardwick, Hoagland, Sanders, White, and Woolf.

9. For example, see Regosin, 149-224, who regards the metaphors discussed here as variations on the theme of consubstantiality. See also Starobinski's discussion of "identity," 26-34.

\section{Works Cited}

Adorno, T. W. "The Essay as Form." Trans. Bob Hullot-Kentor. New German Critique (Spring-Summer 1984): 151-171.

Anderson, Chris. "Hearsay Evidence and Second Class Citizenship." College English 50 (1988): 300-308.

Bensmaia, Reda. The Barthes Effect: The Essay as Reflective Text. Trans. Pat Fedkiew. Minneapolis: U of Minnesota P, 1987. 
Gass, William. "Emerson and the Essay." Habitations of the Word. New York: Simon and Schuster, 1985. 9-49.

Gerould, Katharine Fullerton. "An Essay on Essays." The North American Review. December 1935: 409-418.

Good, Graham. The Observing Self: Rediscovering the Essay. London: Routledge, 1988.

Hardwick, Elizabeth. Introduction. The Best American Essays 1986. Ed. Elizabeth Hardwick. New York: Ticknor \& Fields, 1986. xiii-xxi.

Hoagland, Edward. "What I Think, What I Am." The Tugman's Passage. New York: Random House, 1982. 24-27.

Huxley, Aldous. Preface. Collected Essays. New York: Harper and Row, 1960. v-xi.

Kauffmann, R. Lane. "The Skewed Path: Essaying as Unmethodical Method." Essays on the Essay. Ed. Alexander J. Butrym. Athens: U of Georgia P, 1989. 221-240.

Klaus, Carl H. "Essayists on the Essay." Literary Nonfiction: Theory, Criticism, and Pedagogy. Ed. Chris Anderson. Carbondale: Southern Illinois UP, 1989. 155-175.

Kazin, Alfred. "The Essay as a Modern Form." The Open Form: Essays for Our Time. New York: Harcourt, 1961. vii-xi.

Montaigne, Michel de. The Complete Works of Montaigne. Trans. Donald M. Frame. Stanford: Stanford UP, 1957.

O’Neill, John. Essaying Montaigne. London: Routledge \& Kegan Paul, 1982.

Regosin, Richard L. The Matter of My Book: Montaigne's Essais as the Book of the Self. Berkeley: U of California P, 1977.

Sanders, Scott Russell. "The Singular First Person." Essays on the Essay. Ed. Alexander J. Butrym. Athens: U of Georgia P, 1989. 31-42.

Starobinski, Jean. Montaigne in Motion. Trans. Arthur Goldhammer. Chicago: U of Chicago P, 1984.

White, E. B. Foreword. Essays of E. B. White. New York: Harper and Row, 1977. vii-ix.

Woolf, Virginia. “The Modern Essay." In Vol. 2 of Collected Essays. New York: Harcourt Brace World, 1967. 